\title{
Selection of appropriate reinforcement for nylon material through mechanical and damping characteristics
}

\author{
Hari Bodipatti Subburamamurthy ${ }^{1}$ (D), Rajasekar Rathanasamy ${ }^{*}$ (D), Harikrishna Kumar Mohan Kumar ${ }^{1}$ (D), \\ Moganapriya Chinnasamy $^{1}$ (D), Gobinath Velu Kaliyannan² and (D) and Saravanan Natarajan ${ }^{1}$ (D) \\ 'Department of Mechanical Engineering, Kongu Engineering College, Erode, Tamil Nadu, India \\ ${ }^{2}$ Department of Mechatronics Engineering, Kongu Engineering College, Erode, Tamil Nadu, India \\ *rajasekar.cr@gmail.com
}

\begin{abstract}
Nylon composites were developed using 5-20 wt.\% of Talc, Kaolin, Mica and Calcium Carbonate $\left(\mathrm{CaCO}_{3}\right)$ particulates. Mechanical and free vibration characteristics of nylon composites were examined through experimental and analytical approach. Particulate filled nylon composites exhibited enhancement in tensile strength, specific stiffness, natural frequency and damping factor compared to pure nylon. As a whole, talc reinforced nylon composites especially $15 \mathrm{wt} . \%$ filler content (T15) portrayed significant performance in mechanical and vibrational characteristics. This is followed by nylon composites based on kaolin (K15) and mica (M20) compared to $\mathrm{CaCO}_{3}$ based nylon composites. T15 depicted $18.13 \%, 33.33 \%, 81.2 \%$ increment in tensile strength, natural frequency and damping factor compared to pure nylon. The simulated ANSYS results are in agreement with experimental results. Among four different particulates, talc is proven as appropriate reinforcing agent for nylon owing to larger surface area of talc particles and polar-polar interaction between talc and nylon matrix.
\end{abstract}

Keywords: damping factor, mechanical testing, mineral fillers, nylon 6.

How to cite: Subburamamurthy, H. B., Rathanasamy, R., Kumar, H. K. M., Chinnasamy, M., Kaliyannan, G. V., \& Natarajan, S. (2020). Selection of appropriate reinforcement for nylon material through mechanical and damping characteristics. Polímeros: Ciência e Tecnologia, 30(4), e2020046. https://doi.org/10.1590/0104-1428.05520

\section{Introduction}

Nylon is made with combining appropriate monomers to form a long chain by condensation polymerization reaction followed by granulation. It contains oxygen, nitrogen and hydrogen atoms. Nylon is the widely used polymer due to its commendable mechanical properties and processability. The nylon is used in many engineering applications due to its high abrasion resistance, noiseless operation and self-lubricating property, since it is used in places where lubrication cannot be provided (i.e., textile machines, washing machines, automobiles, aerospace, printers, etc...).

Pure nylon has moderate mechanical properties and vibrational characteristics and it is not preferred in some engineering applications due to its limitations such as poor resistance to heat, low dimensional stability, high water absorption ${ }^{[1-4]}$. Researchers overcome the stated limitations through the development of nylon composites by incorporating fibers or fillers ${ }^{[5-7]}$. Particulates like carbon nanotubes, graphene, zinc oxide, talc, mica, calcium carbonate, kaolin, etc., are used for the preparation of nylon composites / nanocomposites. It was evident that the improvement in physical and mechanical properties of particulate based polymer composites depends on the structural geometry of the particle (i.e., shape, size, surface area) and extent of distribution of particles in the polymer matrices ${ }^{[3,11]}$. Mineral fillers are available in different forms such as sphere, cube,

sheets, flakes, plates and fibers ${ }^{[7]}$. Mechanical properties like tensile strength, modulus, impact strength and stiffness were increased upon adding nano fillers to the nylon matrix, whereas the cost of nano fillers were high ${ }^{[7,17,20]}$. The mineral fillers with larger particle size $(\mu \mathrm{m})$ also increased the mechanical properties with less $\cos ^{[6,8-10]}$. The natural fibers like kenaf, flax, hemp etc., were also added to nylon to improve the properties. However, processing of natural fiber based nylon composites are challenging owing to low thermal stability of natural fibers. The properties of natural fiber polymer composites depends on the properties, orientation and concentration of fibers ${ }^{[11]}$. Natural fiber composites cannot be used for many applications like gears, bushings, fasteners, etc. The particulate filled composites can be processed easily and applied in many applications than fiber composites ${ }^{[13-21]}$.

The present research work utilizes talc, kaolin mica and $\mathrm{CaCO}_{3}$. Talc contains magnesium - silica, kaolin contains aluminium - silica, mica contains aluminium-magnesiumiron-silica combinations ${ }^{[7,10,12]}$. Whereas $\mathrm{CaCO}_{3}$ contains calcium. Talc, kaolin, mica and $\mathrm{CaCO}_{3}$ have polar groups which can form chemical interaction with polar nylon matrix $^{[7,12,14]}$.

Based on the observation from literature survey, it is evident that the studies on vibration behaviour of nylon 
composites is not yet explored. This present research study stands unique in analysing the vibrational characteristics of four different particulate reinforced nylon composites in addition to mechanical performance.

Mineral fillers such as talc, kaolin, mica and $\mathrm{CaCO}_{3}$ particulates are reinforced into the Nylon 6 base matrix using melt mixing method ${ }^{[10,21-23]}$. Extruded nylon composites were palletized and the samples for vibration and tensile studies were prepared using injection moulding machine. Tensile strength and stiffness were determined using tensometer. Natural frequency and damping factor were measured by performing modal analysis. The natural frequency and damping factor are considered as an important vibration parameter, when the material is subjected to both constant and cyclic loading ${ }^{[24-26]}$. The mechanical properties and modal analysis of the composites were also simulated using ANSYS 18.1 software and simulated results were compared with experimental results.

\section{Materials and Methods}

\subsection{Materials}

The material used in this research work was nylon 6 (PA6) pellets, were procured from ARS polymers, Coimbatore, India. The technical grade mineral fillers (talc, kaolin, mica and $\mathrm{CaCO}_{3}$ ) were purchased from Astrra Chemicals, Chennai, India and its properties is listed in Table 1.

\subsection{Sample preparation}

Initially fillers (talc, kaolin, mica and $\mathrm{CaCO}_{3}$ ) and Nylon 6 were dried at $80^{\circ} \mathrm{C}$ for 1 hour using hot air oven to remove the moisture content. The materials are allowed to cool inside the oven to prevent oxidization. The nylon 6 does not lead to any structural change up to $150^{\circ} \mathrm{C}$.

Fillers (talc, kaolin, mica and $\mathrm{CaCO}_{3}$ ) and nylon 6 were melt mixed and extruded using twin extruder according to the formulation table shown in Table 2. The extruder was operated at $50 \mathrm{rpm}$ and at $240{ }^{\circ} \mathrm{C}$. Due to corotation and intermeshing of the screws, the melt mixed nylon with filler were extruded. The extruded materials were palletized is used for preparing tensile and vibration samples with injection molding machine. Injection molding machine was operated at $280^{\circ} \mathrm{C}$, injection and holding pressure was maintained at $78 \times 10^{5} \mathrm{~Pa}$ and $35 \times 10^{5} \mathrm{~Pa}$ respectively. Preparation method of the composite was described in Figure 1.

\subsection{Characterization techniques}

\subsubsection{Mechanical testing}

Tensile specimens were prepared according to ASTM D638 standard. Tensile test were carried out using electronic tensometer (PC2000-20 kN capacity) and the tensometer was operated with a crosshead speed of $1 \mathrm{~mm} / \mathrm{min}$ using the load cell of $5 \mathrm{kN}$. Tensile strength and modulus of elasticity were determined for three specimens in each category of composites. Average values of three samples were reported in this work.

Tensile strength was also verified using ANSYS R18.1 software. H-method structural analysis with Solid quad
Table 1. Material properties of fillers.

\begin{tabular}{lcccc}
\hline & Talc & Kaolin & Mica & CaCO $_{3}$ \\
\hline Grain Size $(\mu \mathrm{m})$ & 1 to 1.5 & 1 to 10 & 1 to 20 & $\leq 50$ \\
Grain shape & Platy & $\begin{array}{c}\text { Tetra/ } \\
\text { octahedral } \\
\text { sheet }\end{array}$ & $\begin{array}{c}\text { No proper } \\
\text { shape }\end{array}$ & Orthorhombic \\
Density $(\mathrm{g} / \mathrm{cc})$ & 2.76 & 2.59 & 2.90 & 2.70 \\
\hline
\end{tabular}

Table 2. Formulation of compounds.

\begin{tabular}{lccccc}
\hline \multirow{2}{*}{$\begin{array}{c}\text { Sample } \\
\text { code }\end{array}$} & $\begin{array}{c}\text { Nylon 6 } \\
\text { wt. \% }\end{array}$ & \multicolumn{5}{c}{ Filler material wt. \% } \\
\cline { 3 - 6 } & 100 & Talc & Kaolin & Mica & CaCO $_{3}$ \\
\hline N & 95 & 5 & - & - & - \\
T 5 & 90 & 10 & - & - & - \\
T 10 & 85 & 15 & - & - & - \\
T 15 & 80 & 20 & - & - & - \\
T 20 & 95 & - & 5 & - & - \\
K 5 & 90 & - & 10 & - & - \\
K 10 & 85 & - & 15 & - & - \\
K 15 & 85 & - & 20 & - & - \\
K 20 & 80 & - & - & 5 & - \\
M 5 & 95 & - & - & 10 & - \\
M 10 & 90 & - & - & 15 & - \\
M 15 & 85 & - & - & 20 & - \\
M 20 & 80 & - & - & - & 5 \\
C 5 & 95 & - & - & - & 10 \\
C 10 & 90 & - & - & - & 15 \\
C 15 & 85 & - & - & - & 20 \\
C 20 & 80 & - & - & - & \\
\hline
\end{tabular}

4 node 182 element type was used for analysis. A model was created according to the ASTM D638 standard using Creo 4.0 and the model is imported to ANSYS. The material properties obtained from experimental analysis is given as input to ANSYS specimen. Tetrahedral mesh was done to fit the tensile specimen geometry. The displacement was constrained at one end with all DOF fixed and force was defined along the X-axis on other end. Model was solved and the solutions were obtained.

\subsubsection{Modal analysis}

Nylon composite was prepared with the size of $200 \mathrm{~mm} \times 20 \mathrm{~mm} \times 3 \mathrm{~mm}$. Experimental setup of modal analysis used in this work is shown in Figure 2. Free vibration analysis technique was used to carry out modal analysis with cantilever beam. One end of the composite beam was fixed and piezoelectric sensor was fixed on the other end. Data acquisition card (NI USB 6008 DAQ) used as an interface between Lab VIEW 2016 software and the piezoelectric sensor. The beam was subjected to free oscillation on the free end to obtain the time domain signals using Lab VIEW software. A circuit was designed using Lab VIEW software to convert the time domain signals into frequency domain signals. The signal was sampled with sampling rate $n=1000 \mathrm{samples} / \mathrm{sec}$ and sampling time $\mathrm{T}=10 \mathrm{sec}$. Obtained frequency domain signals were stored in a computer for further analysis.

The half-power band width method was used to find the damping coefficient values of nylon composites through frequency response function (FRF) curves obtained from the Lab VIEW software. Band width values are obtained 


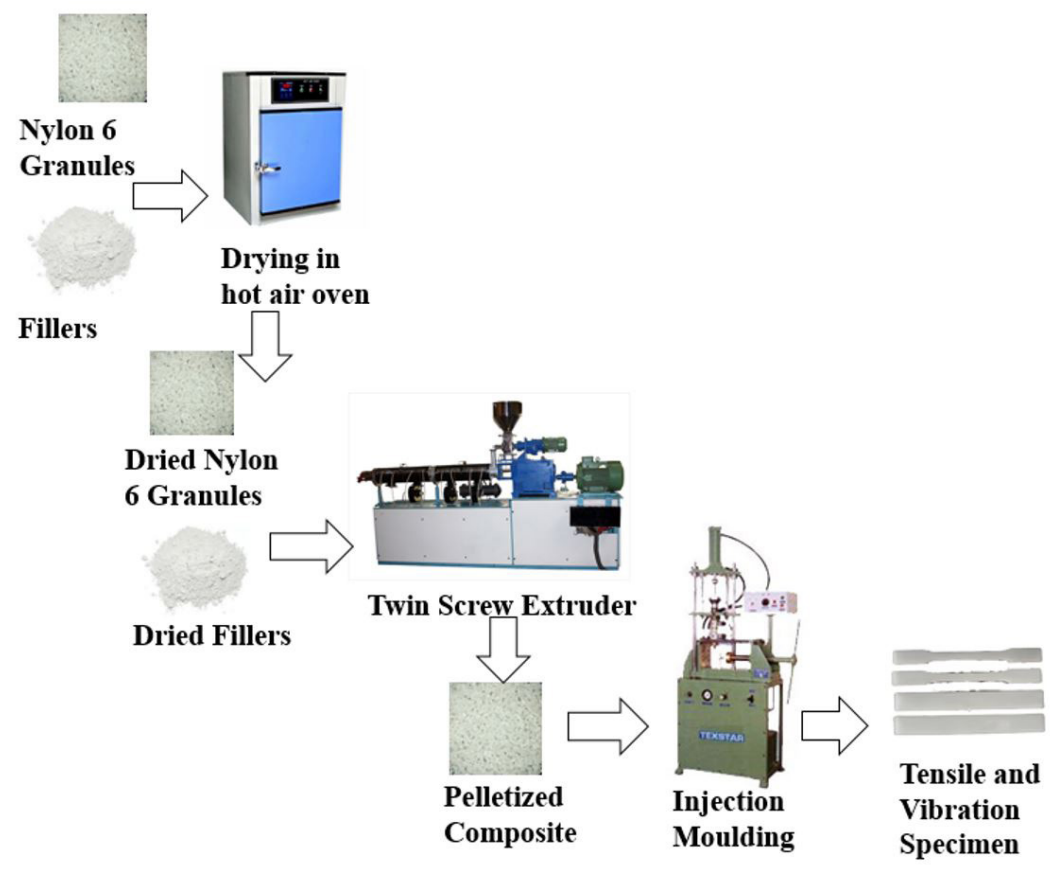

Figure 1. Specimen preparation.

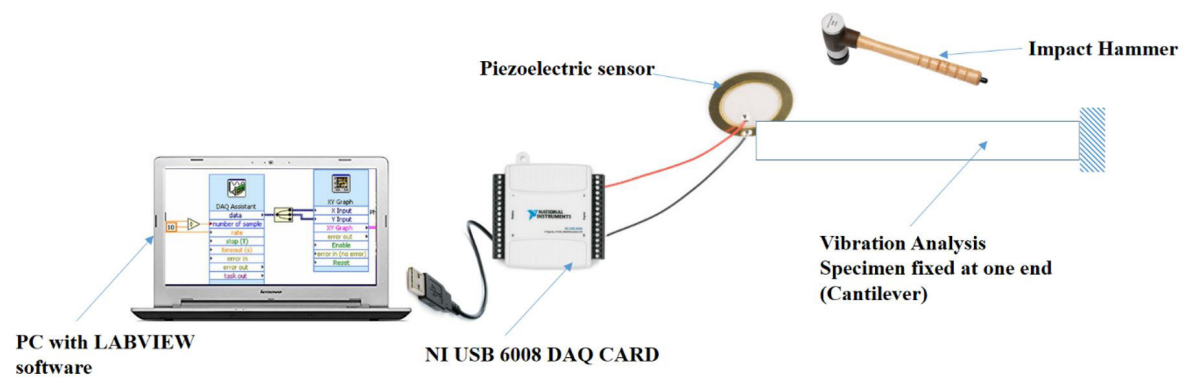

Figure 2. Experimental setup for modal analysis.

from the sample frequency curve shown in Figure 3. In accordance, the damping values were calculated based on Equation 1. Initial vibration amplitude (mode 1) is considered for calculating natural frequency and damping factor of the composite.

$$
\zeta=\Delta \omega / 2 \omega n
$$

Where, $\zeta$ - damping coefficient, $\Delta \omega$ - bandwidth, and $\omega \mathrm{n}$ - natural frequency.

Modal analysis was also carried out using ANSYS software. Beam was modelled in the software and the element type used was selected as beam 2 node 188 . The material properties and the real constants were defined with reference to the specimen properties. Meshing was performed with 10 as element size. Modal analysis type was selected and three modes of frequency were extracted during the analysis. Degrees of freedom were arrested on one end of the beam and natural frequency was obtained on solving the above-mentioned criteria.

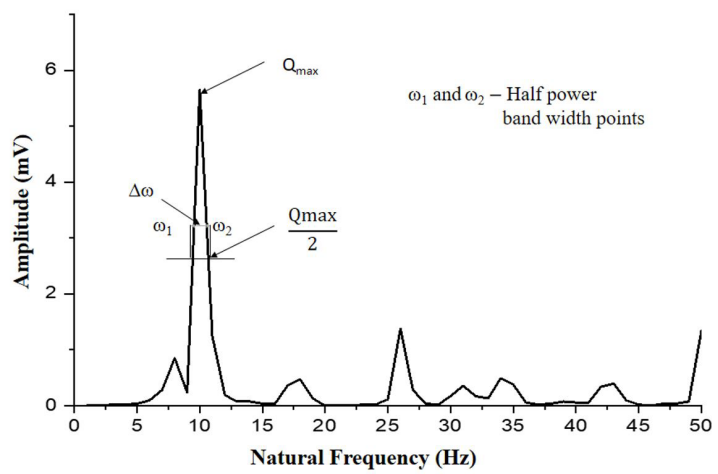

Figure 3. Sample frequency curve.

\section{Results and Discussions}

\subsection{Mechanical testing}

Modulus of elasticity of the prepared composites are shown in Figure 4. It is evident that addition of particulates 


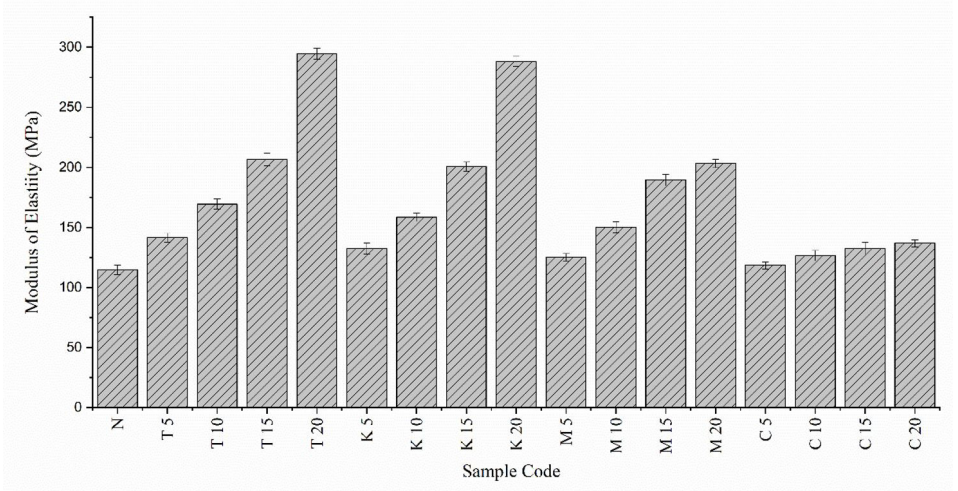

Figure 4. Effect of particulates on modulus of elasticity.

enhanced the modulus of elasticity of nylon composites compared to pure nylon. Moreover, increase in concentration of particulates in the nylon matrix gradually increase the elastic modulus. Modulus of elasticity of talc, kaolin, mica and $\mathrm{CaCO}_{3}$ particulates reinforced composites (T20, K20, M20 and C20) was increased by $156 \%, 151.3 \%, 77.2 \%$ and $19.3 \%$ respectively compared to pure nylon. The possible reasons are depicted as follows. Addition of rigid particles in low stiffness polymer like nylon can cause increase in elastic modulus. Secondly, incorporated particulates create strong physical interaction with the nylon matrix, thereby restricting the movement of the polymer chains causing increment in modulus ${ }^{[27]}$. However, talc, kaolin and mica reinforced system showed pronounced effect of elastic modulus increment than $\mathrm{CaCO}_{3}$. In reference to base chemical structure of reinforcements and nylon (Table 3 ), it is affirmed that there exists hydrogen bonding between talc-nylon, kaolin-nylon and mica-nylon. Hence, it is evident that apart from physical interaction, the chemical interaction also plays a vital role in improvement of elastic modulus. On the other hand, there is no chemical interaction between $\mathrm{CaCO}_{3}$-nylon matrix and hence there was a marginal increase in elastic modulus due to physical interaction between the two.

Figure 5 shows the tensile strength of the pure and talc, kaolin, mica and $\mathrm{CaCO}_{3}$ filled nylon composites obtained through experimental method and ANSYS simulation method. Talc, kaolin and mica reinforced nylon composites shows increase in tensile strength compared to pure nylon matrix. Talc and Kaolin reinforced composites showed a similar trend, i.e., the tensile strength gradually increased with increase in addition of particulates upto $15 \mathrm{wt} . \%$ and further drops, while increasing the loading to $20 \mathrm{wt} . \%$. The increase in tensile strength can be attributed to homogeneous distribution of particulates in nylon matrix and the drop in tensile strength (T 20 \& K 20) can be ascribed to agglomeration of particulates due to higher loading beyond the acceptable limit. In case of mica reinforced composites, the tensile strength increased with gradual increase in loading of mica (5-20 wt.\%). Platy fillers have high aspect ratio, which increases the wettability of fillers by the matrix. Further addition of filler reduces the mobility of polymer chains and affects the kinetics of crystallisation. However, $\mathrm{CaCO}_{3}$ based nylon composites showed consecutive drop in tensile strength with gradual increase in addition of particulate. $\mathrm{CaCO}_{3}$ is known to promote craze formation in deformed

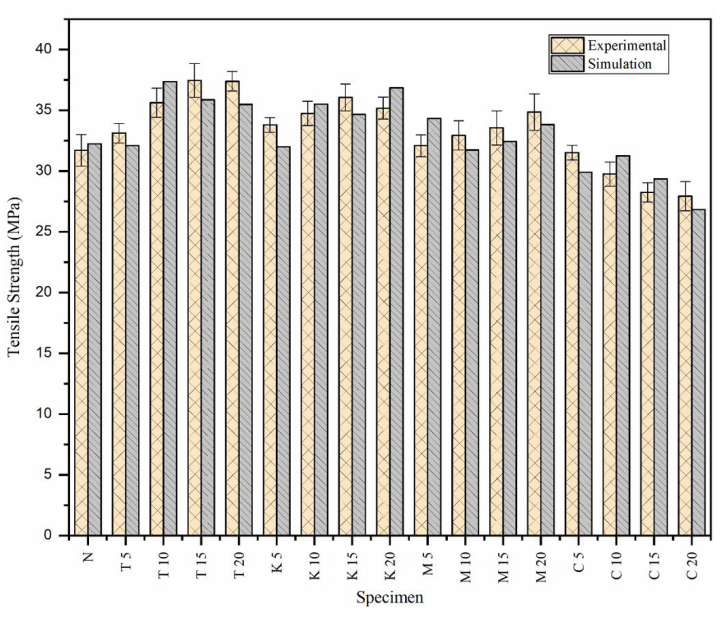

Figure 5. Effect of particulates on tensile strength.

polymers before fracture and low surface tension. This causes dewetting of $\mathrm{CaCO}_{3}$ particles from the nylon matrix. Dewetting becomes more evident as the concentration of the filler increases. Also filler-matrix adhesion is relatively weak, allowing debonding to occur before fully developed plastic deformation and therefore, the formation of cavities. The particle size of $\mathrm{CaCO}_{3}$ is comparatively higher than other three fillers.

Talc reinforced nylon composites showed superior tensile strength followed by kaolin and mica based systems compared to $\mathrm{CaCO}_{3}$ containing nylon composites. The structural backbone with presence of elements like $\mathrm{Si}$, $\mathrm{Mg}, \mathrm{Al}$ imparts strength and stiffness to talc, kaolin and mica. Hence, incorporation of the same in nylon leads to elevation in tensile strength. On the other hand, $\mathrm{CaCO}_{3}$ has a weak structural backbone bearing only calcium content and hence, incorporation of the same in nylon detoriate the tensile strength.

The increment in tensile strength of T $15, \mathrm{~K} 15$ and M 20 was $18 \%, 14 \%$ and $10 \%$ compared to pure nylon. Hence, T 15 was confirmed as the suitable particulate and optimized filler concentration for nylon.

Figure 6 shows the meshing of the tensile specimen using tetrahedral elements. Figure $7 \mathrm{a}$ and Figure $7 \mathrm{~b}$ shows the tensile strength obtained from ANSYS software for 
Table 3. Interaction of polymer matrix and reinforcement.

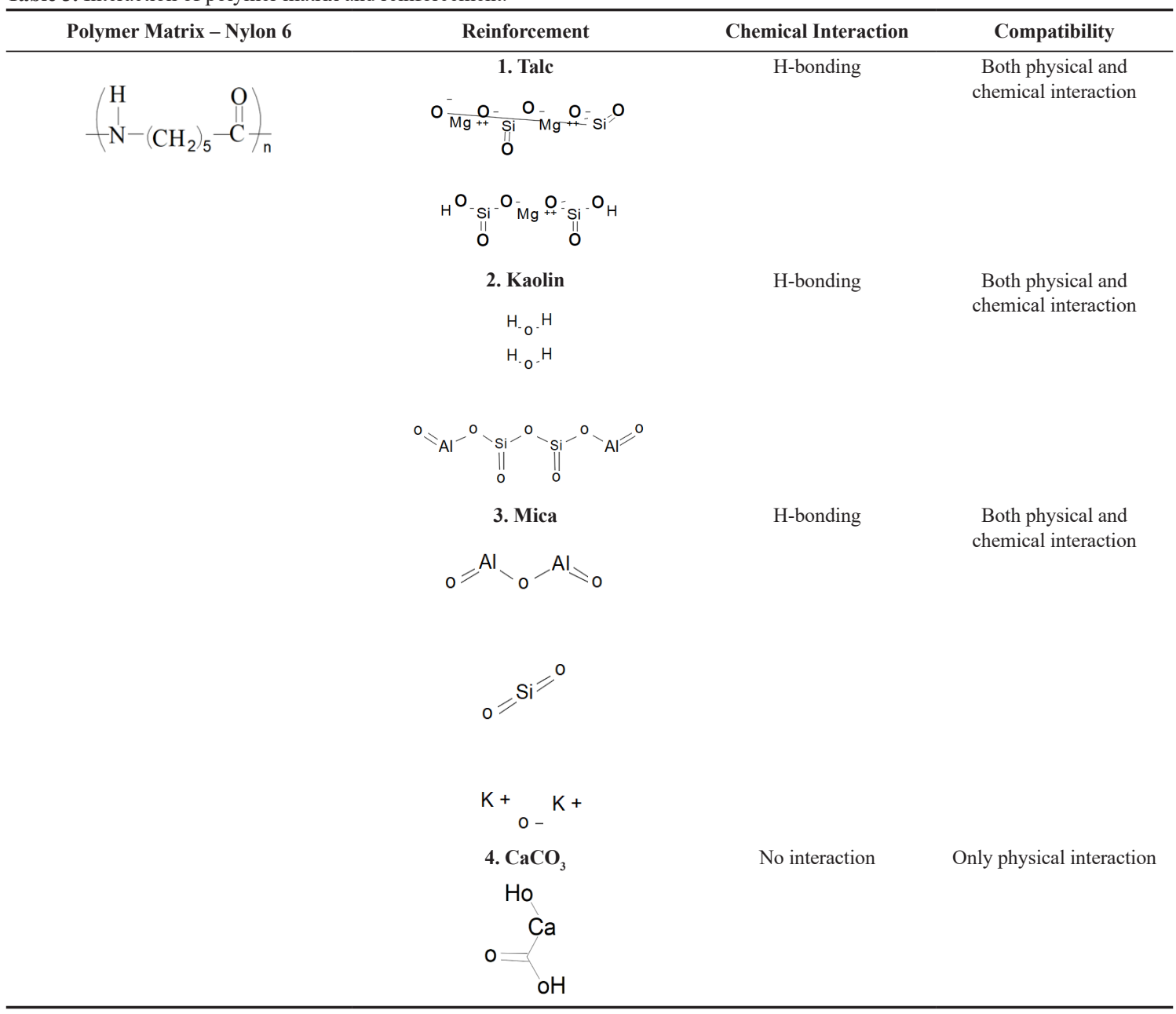

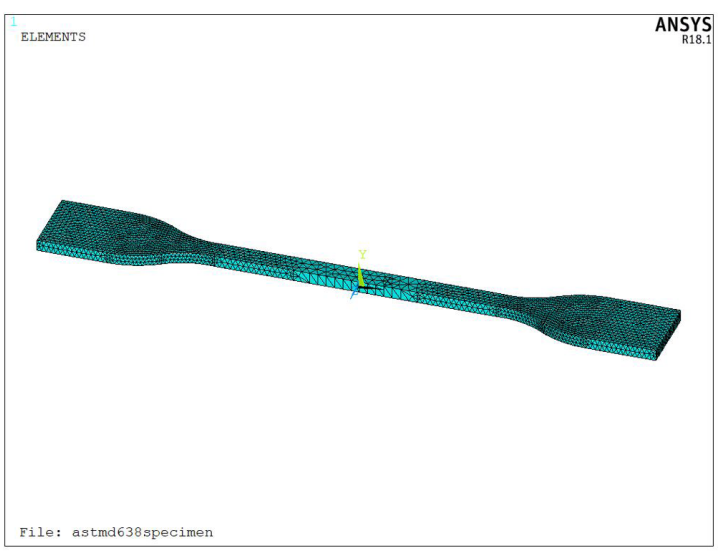

Figure 6. Meshing of tensile specimen in ANSYS.

T15 and K15 specimens respectively. Difference between experimental and ANSYS results of tensile strength were calculated in terms of coefficient of variation and it was found to be $5.3 \%$. Hence both experimental and ANSYS results were found to be similar.

Figure 8 shows the graph plotted against specific stiffness and specific strength. Specific strength and specific stiffness of the composite relies on tensile strength, modulus of elasticity and density of the composites. Specific stiffness and strength increases as weight content of filler increases in nylon matrix. Maximum specific stiffness was achieved for the composites (T20, K20, M20 and C20) with high filler content. Despite T20 and K20 achieved maximum specific stiffness, tensile strength of those composites was reduced when compared to composites T15 and K15. Among the T15, K15, M20 and C20 composite T15 composite achieved the maximum specific stiffness due to the density of the composite and the compatibility between filler and nylon matrix resulted in strong interfacial bonding ${ }^{[10]}$.

\subsection{Modal analysis}

Modal analysis was performed for the prepared nylon composites using the experimental setup. Natural frequency and damping factor have been obtained for all the prepared composites to analyse the effect of addition of filler in nylon using free vibration technique. Modal analysis was also carried out using ANSYS software and the ANSYS images of T15 and K15 composites were shown in Figure 9a and Figure $9 \mathrm{~b}$ respectively. Figure 10, shows the natural frequency values obtained experimentally and by simulation using ANSYS software. 

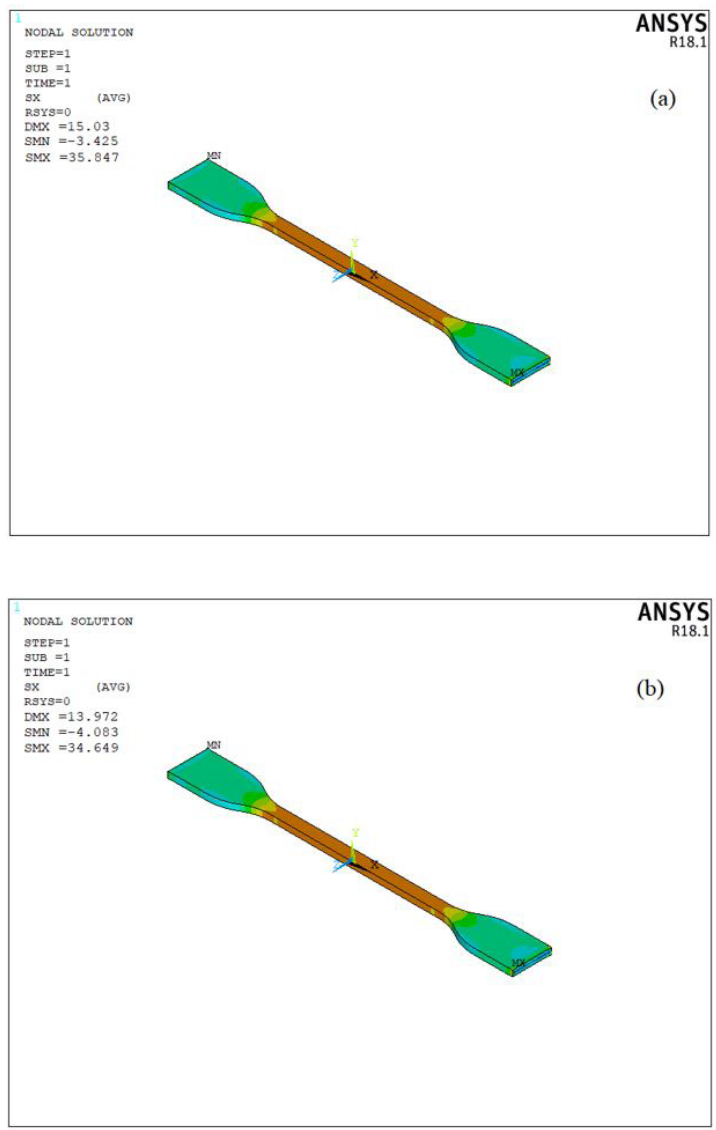

Figure 7. Tensile strength analysis using ANSYS of (a) T 15 (b) K 15.

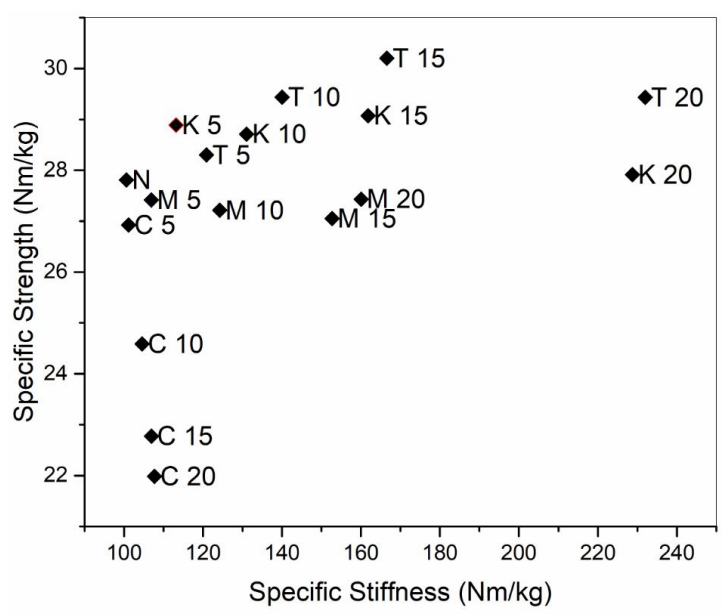

Figure 8. Effect of fillers on specific stiffness and specific strength of composites.

Natural frequency increases as quantity of filler increases in base matrix. Enhancement in natural frequency was achieved based on the increase in stiffness of the beam, modulus of elasticity and interfacial bonding between filler - base matrix ${ }^{[24-26]}$. Natural frequency of the composite (T15, K15 and M20) was increased by $33.33 \%, 16.66 \%$ and $16.66 \%$ respectively when compared to pure nylon $(\mathrm{N})$. Whereas natural frequency of $\mathrm{CaCO}_{3}$ composite decreases when
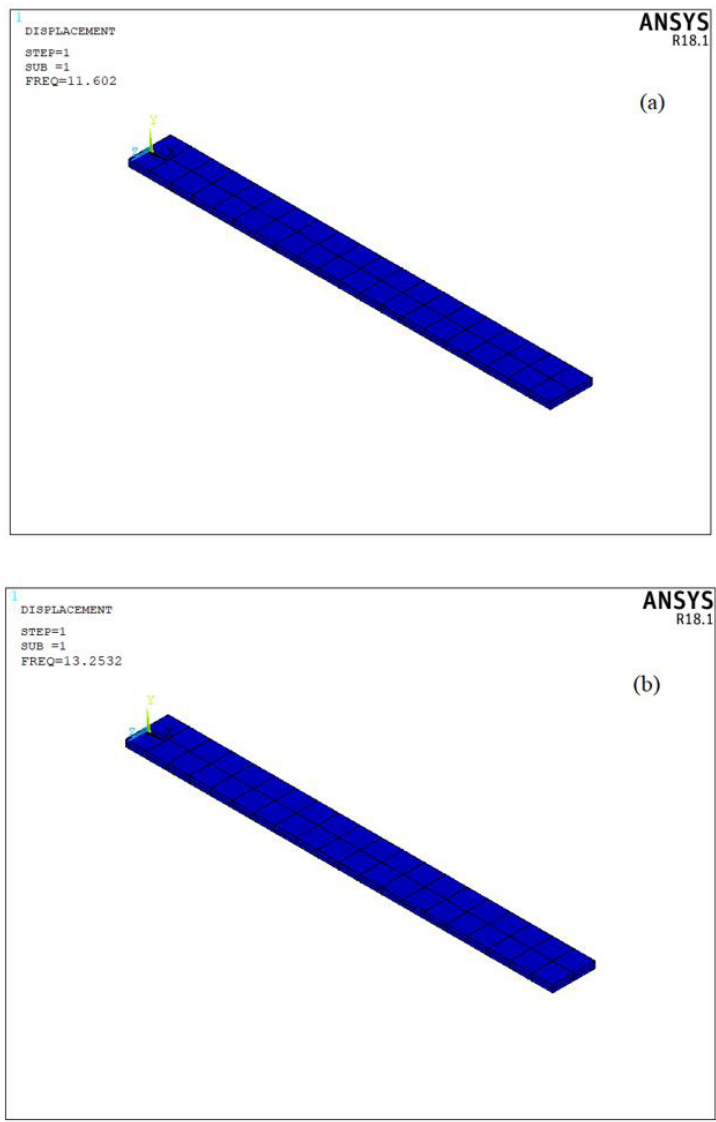

Figure 9. Modal analysis using ANSYS of (a) T15 (b) K15.

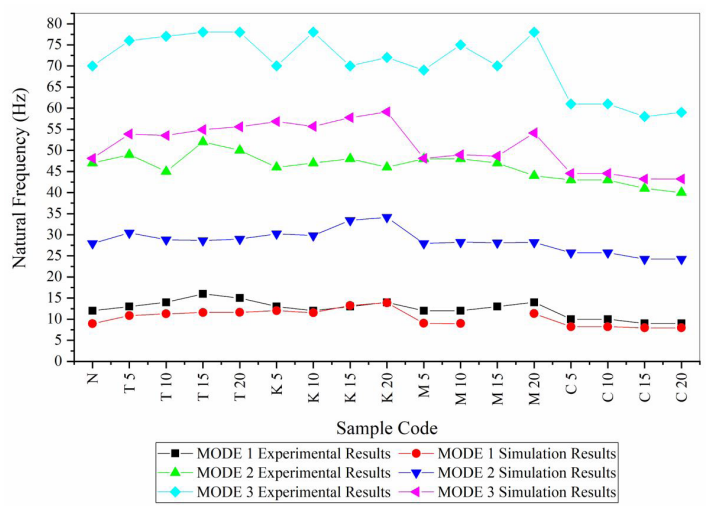

Figure 10. Natural frequency of composite specimens.

compared to pure nylon (N). Natural frequency obtained from modal analysis using ANSYS software follows the similar pattern of experimental results. Difference between experimental and ANSYS results were determined in coefficient of variation with $3.64 \%$ deviation.

Figure 11 shows the damping factor for the prepared composites. Damping factor increases as weight content of filler increases in nylon matrix. Among the prepared composites T15, K15 and M15 composite shows maximum damping factor. Damping factor of T15, K15 and M15 composite increases by $81.2 \%, 54.24 \%$ and $46.72 \%$ respectively when 


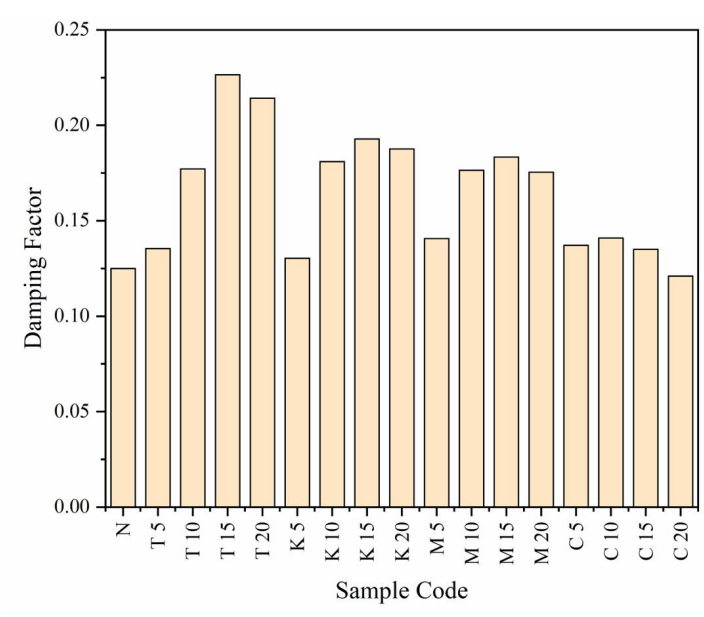

Figure 11. Damping factor of the composite specimens.

compared to pure nylon $(\mathrm{N})$. The T15 specimen has higher frequency, even though it has a high damping value due to the major difference in half power band width $(\Delta \omega)$. The higher damping factor implies that the material withstands more loads and shocks ${ }^{[24]}$. Maximum damping factor was achieved due to the major difference in half power band width $(\Delta \omega)$. Maximum damping factor indicates that nanocomposite can absorb amount of vibration energy ${ }^{[25]}$.

\section{Conclusions}

Nylon composites were prepared by incorporating mineral fillers (Talc, Kaolin, Mica and $\mathrm{CaCO}_{3}$ ) into nylon matrix. Fillers were mixed with nylon using melt mixing method and specimens were moulded using injection moulding machine. Composites were prepared by reinforcing fillers with $5,10,15$ and 20 wt. \% into nylon matrix. Tensile strength, modulus of elasticity, specific stiffness, and specific strength were examined to study the mechanical behaviour of composite. Modal analysis were also carried out for the prepared composite to determine vibration characteristics of the composites. Tensile strength and natural frequency of the composite were also determined using ANSYS and both the results were compared for validation. Increase in filler (talc, kaolin and mica) content in nylon matrix increases the tensile strength, specific stiffness, natural frequency and damping factor. Larger surface area of the filler leads to the strong interfacial bonding between filler and nylon matrix. Tensile strength was reduced during the addition of $\mathrm{CaCO}_{3}$ filler in nylon matrix. T15 (talc with 15 wt.\%) composite shows superior mechanical and vibration characteristics when compared with all other composites. Tensile strength and natural frequency of ANSYS results also followed the similar pattern of experimental results. Tensile strength and natural frequency of both results were compared and difference in coefficient of variation was found to be $5.3 \%$ and $3.64 \%$ respectively.

\section{References}

1. Bose, S., \& Mahanwar, P. (2004). Effect of particle size of filler on properties of nylon-6. Journal of Minerals \& Materials
Characterization \& Engineering, 3(1), 23-31. http://dx.doi. org/10.4236/jmmce.2004.31003.

2. Bose, S., \& Mahanwar, P. (2005). Influence of particle size and particle size distribution on MICA filled nylon 6 composite. Journal of Materials Science, 40(24), 6423-6428. http://dx.doi. org/10.1007/s10853-005-2024-6.

3. Unal, H., Findık, F., \& Mimaroglu, A. (2003). Mechanical behavior of nylon composites containing talc and kaolin. Journal of Applied Polymer Science, 88(7), 1694-1697. http:// dx.doi.org/10.1002/app.11927.

4. Lapčík, L., Maňas, D., Lapčíková, B., Vašina, M., Staněk, M., Čépe, K., Vlček, J., Waters, K. E., Greenwood, R. W., \& Rowson, N. A. (2018). Effect of filler particle shape on plasticelastic mechanical behavior of high density poly (ethylene)/ mica and poly (ethylene)/wollastonite composites. Composites. Part B, Engineering, 141, 92-99. http://dx.doi.org/10.1016/j. compositesb.2017.12.035.

5. Abu Bakar, M., Leong, Y., Ariffin, A., \& Mohd Ishak, Z. A. (2008). Effect of chemical treatments on the mechanical, flow, and morphological properties of talc-and kaolin-filled polypropylene hybrid composites. Journal of Applied Polymer Science, 110(5), 2770-2779. http://dx.doi.org/10.1002/app.28791.

6. Jang, K.-S. (2016). Mineral filler effect on the mechanics and flame retardancy of polycarbonate composites: talc and kaolin. e-Polymers, 16(5), 379-386. http://dx.doi.org/10.1515/ epoly-2016-0103.

7. Xanthos, M. (2010). Functional fillers for plastics. Germany: John Wiley \& Sons. http://dx.doi.org/10.1002/9783527629848.

8. Ouchiar, S., Stoclet, G., Cabaret, C., Georges, E., Smith, A., Martias, C., Addad, A., \& Gloaguen, V. (2015). Comparison of the influence of talc and kaolinite as inorganic fillers on morphology, structure and thermomechanical properties of polylactide based composites. Applied Clay Science, 116, 231-240. http://dx.doi.org/10.1016/j.clay.2015.03.020.

9. Zhang, Z.-X., Zhao, X.-P., Sun, B., Ma, Z.-G., Xin, Z. X., \& Prakashan, K. (2017). Synergistic effects of kaolin and talc in a bromobutyl rubber compound for syringe plunger application. Journal of Elastomers and Plastics, 49(1), 12-22. http://dx.doi. org/10.1177/0095244315620915.

10. Leong, Y., Abu Bakar, M., Ishak, Z. M., Ariffin, A., \& Pukanszky, B. (2004). Comparison of the mechanical properties and interfacial interactions between talc, kaolin, and calcium carbonate filled polypropylene composites. Journal of Applied Polymer Science, 91(5), 3315-3326. http://dx.doi.org/10.1002/app.13542.

11. Ozen, E., Kiziltas, A., Kiziltas, E. E., \& Gardner, D. J. (2013). Natural fiber blend-nylon 6 composites. Polymer Composites, 34(4), 544-553. http://dx.doi.org/10.1002/pc.22463.

12. Larrañaga, M. D., Lewis, R. J., \& Lewis, R. A. (2016). Hawley's condensed chemical dictionary. USA: John Wiley \& Sons. http://dx.doi.org/10.1002/9781119312468.

13. Unal, H., Mimaroglu, A., \& Alkan, M. (2004). Mechanical properties and morphology of nylon-6 hybrid composites. Polymer International, 53(1), 56-60. http://dx.doi.org/10.1002/ pi.1246.

14. Bakar, M. A., Leong, Y., Ariffin, A., \& Ishak, Z. M. (2007). Mechanical, flow, and morphological properties of talc-and kaolin-filled polypropylene hybrid composites. Journal of Applied Polymer Science, 104(1), 434-441. http://dx.doi.org/10.1002/ app.25535.

15. Kumar, K. V. M., Krishnamurthy, K., Rajasekar, R., Kumar, P. S., Pal, K., \& Nayak, G. C. (2019). Influence of graphene oxide on the static and dynamic mechanical behavior of compatibilized polypropylene nanocomposites. Materials Testing, 61(10), 986-990. http://dx.doi.org/10.3139/120.111411.

16. Kumar, M. K. H., Shankar, S., Rajasekar, R., Kumar, P. S., \& Kumar, P. S. (2017). Partial replacement of carbon black by nanoclay 
in butyl rubber compounds for tubeless tires. Materials Testing, 59(11-12), 1054-1060. http://dx.doi.org/10.3139/120.111109.

17. Mohan Kumar, H. K., Subramaniam, S., Rathanasamy, R., Pal, S. K., \& Palaniappan, S. K. (2020). Substantial reduction of carbon black and balancing the technical properties of styrene butadiene rubber compounds using nanoclay. Journal of Rubber Research, 23(2), 79-87. http://dx.doi.org/10.1007/s42464-020-00039-7.

18. Koo, J. H. (2006). Polymer nanocomposites: processing, characterization, and applications. USA: McGraw Hill Education.

19. Das, C., Rajasekar, R., Friedrich, S., \& Gehde, M. (2011). Effect of nanoclay on vibration welding of LLDPE nanocomposites in presence and absence of compatibiliser. Science and Technology of Welding and Joining, 16(2), 199-203. http://dx.doi.org/10. 1179/1362171810Y.0000000017.

20. Araújo, E. M., Mélo, T. J. A., Santana, L. N. L., Neves, G. A., Ferreira, H. C., Lira, H. L., Carvalho, L. H., A'vila, M. M., Jr., Pontes, M. K. G., \& Araújo, I. S. (2004). The influence of organobentonite clay on the processing and mechanical properties of nylon 6 and polystyrene composites. Materials Science and Engineering B, 112(2-3), 175-178. http://dx.doi.org/10.1016/j. mseb.2004.05.027.

21. Fornes, T., \& Paul, D. (2003). Formation and properties of nylon 6 nanocomposites. Polímeros: Ciência e Tecnologia, 13(4), 212-217. http://dx.doi.org/10.1590/S0104-14282003000400004.

22. Huber, T., Misra, M., \& Mohanty, A. K. (2014). Mechanical properties of compatibilized nylon 6/polypropylene blends; studies of the interfacial behavior through an emulsion model. Journal of Applied Polymer Science, 131(18), 40792. http:// dx.doi.org/10.1002/app.40792.
23. Sangroniz, L., Moncerrate, M. A., De Amicis, V. A., Palacios, J. K., Fernández, M., Santamaria, A., Sánchez, J. J., Laoutid, F., Dubois, P., \& Müller, A. J. (2015). The outstanding ability of nanosilica to stabilize dispersions of nylon 6 droplets in a polypropylene matrix. Journal of Polymer Science. Part B, Polymer Physics, 53(22), 1567-1579. http://dx.doi.org/10.1002/ polb.23786.

24. Frulloni, E., Kenny, J. M., Conti, P., \& Torre, L. (2007). Experimental study and finite element analysis of the elastic instability of composite lattice structures for aeronautic applications. Composite Structures, 78(4), 519-528. http:// dx.doi.org/10.1016/j.compstruct.2005.11.013.

25. Arvinda Pandian, C., \& Siddhi Jailani, H. (2019). Dynamic and vibrational characterization of natural fabrics incorporated hybrid composites using industrial waste silica fumes. International Journal of Polymer Analysis and Characterization, 24(8), 721-730. http://dx.doi.org/10.1080/1023666X.2019.1668141.

26. Rajesh, M., Pitchaimani, J., \& Rajini, N. (2016). Free vibration characteristics of banana/sisal natural fibers reinforced hybrid polymer composite beam. Procedia Engineering, 144, 1055 1059. http://dx.doi.org/10.1016/j.proeng.2016.05.056.

27. Friedrich, K., \& Breuer, U. (2015). Multifunctionality of polymer composites: challenges and new solutions. USA: William Andrew. https://doi.org/10.1016/C2013-0-13006-1.

Received: Jun. 27, 2020

Revised: Feb. 06, 2021 Accepted: Feb. 09, 2021 